\title{
BEYOND CASE LAW: KASTOM AND COURTS IN VANUATU
}

\author{
Miranda Forsyth ${ }^{*}$
}

This article considers the relationship between customary law (kastom) and the official legal system in Vanuatu. It looks at the limitations of the reasons propounded for the lack of integration of customary law and the official legal system and argues that the integration should be a two-way process. The author asserts that a new methodological approach is required to assess the issue regarding the current extent of integration, desirability of integration and capacity for integration of the two systems. Rather than merely analysing case law or legislation, the author argues that the reality behind this picture needs to be investigated and empirical research undertaken.

Cet article analyse les rapports entre le droit coutumier (kastom) et le droit positif en vigueur au Vanuatu. Les différentes raisons qui empêchent la prise en compte du droit coutumier dans le droit positif, sont ainsi successivement envisagées. Au motif que la perméabilité d'un système à l'autre n'est viable que s'il est réciproque, l'auteur considère qu'un tel objectif ne pourra être atteint que si l'on opte pour une méthodologie différente. Devront alors être pris en compte non seulement l'opportunité d'une intégration systématique d'une règle d'un système à l'autre, mais aussi la capacité réelle d'intégration de ces deux systèmes. En fait, les ébauches de solutions ne se trouvent sans doute pas uniquement dans la simple analyse des lois ou des décisions de justice mais aussi dans la réalité sociologique.

The development of a Melanesian jurisprudence has been the Holy Grail for many academics, politicians and judges in Melanesia since the independence of the States in the region. Although views differ on the exact form such jurisprudence might take, it is broadly agreed that it would blend the best elements of both the indigenous (customary) and common law legal systems, creating a culturally relevant, fair and just system. In Vanuatu, the subject of this paper, this ideal has singularly failed to materialise in the twenty years since independence. Rather, the current reality is two legal systems running in parallel: an official (Western) system of courts established by the Constitution, and an unofficial (customary) system administered by communities and chiefs.

* Assistant Lecturer, University of the South Pacific; PhD Candidate, Australian National University. 
Many reasons have been propounded for the lack of integration of customary law and the official legal system. Some commentators have gone so far as to suggest that attempting to integrate the two systems is like trying to mix "oil and water" because of the dichotomies between the two. ${ }^{1}$ Even those who would not go so far stress the extreme difficulties which are entailed in fusing the two systems into a coherent whole. ${ }^{2}$ Thus, the question of the development of an autochthonous legal system in Vanuatu has reached a point and stalled. There is consensus amongst academics that such a development is desirable, even necessary; but the question of which elements of the unofficial system should be integrated and how they could be integrated, given the diverse nature of the two systems, has not yet been investigated.

This paper argues that, in order to advance the matter further, a new methodological approach is required. Rather than approaching the question, as has been done previously, solely by analysing case law and legislation, there needs to be a much broader investigation of the entire justice system, both before and after court, and including both the official and unofficial processes. Only then can a true picture emerge of the current extent of integration, the desirability of integration, and the capacity for integration of the two systems.

Part I of this paper sets out some historical and cultural background about Vanuatu to demonstrate the continued importance of customary traditions and practices. Part II then discusses the official relationship, as proscribed in legislation, between the official legal system and customary law ("kastom"). Part III investigates the actual relationship between the two systems. Part IV considers whether or not there is a desire, outside academic circles, for an integration of the two systems. It finds that while there has not been much research into this question, the evidence that exists suggests that this is the preferred direction for a large percentage of the population. Part V analyses six reasons that have been propounded for the failure of the official system to integrate customary law and processes. It argues that although these reasons prima facie seem to suggest that an integration of the two systems is not possible, in fact these reasons are limited in a number of important respects. It proposes that the question of integration should be viewed as being a two-way, rather than a one-way process, investigating how the official system is influencing the kastom system, as well as the other way around.

The final part VI of the paper suggests that a new way forward is to move beyond case law analysis and study the reality of the operation of the two systems. This section discusses two ethnographic studies which have been made of some hybrid forms of legal systems that spontaneously "mutated" on two of the islands of Vanuatu shortly before independence. It suggests

1 Interview with anonymous source from the Supreme Court of Vanuatu (the author, Vanuatu, 4 July 2003).

2 See for example, David Weisbrot "Custom, Pluralism and Realism in Vanuatu: Legal Development and the Role of Customary Law" (1989) 13 Pac Stud 65; Guy Powles "The Common Law at Bay? The Scope and Status of Customary Law Regimes in the Pacific" (1997) 21 J Pac Stud 61, 75. 
that such studies offer new ideas about the fundamental nature of each system and its ability to change.

\section{VANUATU AND KASTOM}

Vanuatu is a group of 83 islands located in the south west Pacific Ocean, approximately 1700 kilometres east of Australia. Prior to independence in 1980, Vanuatu had been colonised by both the British and the French, who shared power under what was officially known as the "Condominium" and unofficially as the "pandemonium". Today the majority of the population of approximately $200,000^{3}$ are indigenous Melanesians known as Ni-Vanuatu. ${ }^{4}$ There are only two urban centres of any size, namely Port Vila, the national capital on the island of Efate, with a population of 30,000; and Luganville, with a population of 10,000 on the geographically largest island, Espirito Santo. There are large distances between the islands and transportation is expensive. Consequently, the rural areas can be quite isolated from events in the urban areas, and often beyond the reach of the official legal system for all but the most serious of cases.

Vanuatu is one of the most culturally and linguistically diverse countries in the world. ${ }^{5}$ Traditional customs and ways of life are still adhered to by the majority of Ni-Vanuatu, although there have been many changes wrought by missionaries, colonisers and the impact of globalisation. With the rise of the independence movement, and independence itself, there has been a renewed concern with the preservation of traditions and customs, in part as a reaction against westernisation. The term "kastom" is widely employed to describe traditional practices and indigenous ways of doing things. Jolly observed that: ${ }^{6}$

Increasingly the restricted notion of kastom as certain owned aspects of local knowledge and ritual creations has expanded to a notion of kastom as a whole way of life, a culture distinctive of a local group, or a generic indigenous culture opposed to the ways of foreigners.

Kastom also encompasses customary laws, and it is that aspect of kastom that is the focus of this paper. The nature of kastom as a legal system has undergone many changes as a result of colonisation. Pre-colonisation, criminal behaviour was deterred not so much by the threat of specific laws and sanctions, but by the positive power of social ties. If not, the disputes were settled by consensus. The aims of settlement were to make peace between the disputants and to repair or

3 Commonwealth of Australia, Department of Foreign Affairs and Trade, Vanuatu Country Brief <http://www.dfat.gov.au/geo/vanuatu/vanuatu_brief.html> (last accessed 12 May 2004).

4 Meaning "of Vanuatu".

5 When linguists first started to document the language variety in Vanuatu there were 110 languages in existence and many had disappeared as a result of depopulation by introduced diseases.

6 Margaret Jolly "Custom and the Way of the Land: Past and Present in Vanuatu and Fiji" (1992) 62 Oceania 330, 341. 
replace damage. Where consensus could not be reached, "maskat nomo i wok" (the gun alone could settle it). ${ }^{7}$ Dinnen described the situation as follows: ${ }^{8}$

In 'traditional' Melanesia, perceptions and practices of justice reflected the social and political organisation of small, essentially 'stateless', societies. Rather than being centralised in a single entity, authority was typically dispersed throughout the social body. ... There was no concept of 'crime' per se. Disputes were defined and resolved within an elaborate framework of kinship, status and relationships.

Notions of reciprocity and equivalence were also central to the redress of perceived wrongs, as they were to other social activities.

In the pre-colonial era there were many different forms of community leadership - in the north of the country men advanced through "grade societies", acquiring a new title at each stage in part by paying off titleholders above them in sacrificed pigs, mats and food; in the centre patrilineages possessed chiefly titles that were inheritable; and in the south it was different again. ${ }^{9}$ Except in the few areas where chiefs already existed, the British introduced the concept of chiefs into Vanuatu, as they had found that the chiefly structure in Polynesia greatly assisted their colonisation process. ${ }^{10}$ However, despite being an introduced phenomenon, today the chiefly structure has become so far entrenched in kastom as to have become its very cornerstone.

\section{ONE COUNTRY, TWO SYSTEMS}

Today in Vanuatu there are two legal systems: an official and an unofficial system. Commentators on the post-colonial States of Asia, Africa and Latin America have also noted the existence of two "publics" - an official state sector and an ethnically and culturally delineated nonofficial sector. Ibhawoh's observation that "[w]hile the official sector commands considerable political power and authority, it is the unofficial sector, along ethnic/linguistic and cultural lines that commands more loyalty"11 applies also in Vanuatu.

7 Jean Larcom "Custom By Decree: Legitimation Crisis in Vanuatu" in Jocelyn Linnekin and Lin Poyer (eds) Cultural Identity and Ethnicity in the Pacific (University of Hawaii Press, Honolulu, 1990) 175, 178.

8 Sinclair Dinnen "Discussion Paper 02/2: Building Bridges: Law and Justice Reform in Papua New Guinea", 3 <http://rspas.anu.edu.au/melanesia/2002.htm> (last accessed 12 May 2004) (footnote omitted).

9 Lamont Lindstrom "Chiefs in Vanuatu Today" in Geoffrey M White and Lamont Lindstrom (eds) Chiefs Today: Traditional Pacific Leadership and the Postcolonial State (Stanford University Press, California, 1997) 212.

10 Lissant Bolton "Chief Willie Bongmatur Maldo and the Role of Chiefs in Vanuatu" (1998) 33 J Pac Hist 179.

11 Bonny Ibhawoh "Cultural Tradition and National Human Rights Standards in Conflict" in Kristin Hastrup (ed) Legal Cultures and Human Rights: The Challenge of Diversity (Kluwer Law International, The Hague, 2001) 85, 90. 
The official system is that established by the State, which consists of the courts, the police, the Public Prosecutor and the Public Solicitor. The unofficial system, kastom, encompasses the traditional norms of behaviour that are backed up by a sanction of some description (either positive or negative) administered by a member or members of the local community, or a chief at some level of the chiefly hierarchy. It also includes the processes by which disputes are dealt with - as the Chief Justice of Vanuatu has aptly put it, the basket of the law, as well as the contents of the basket. As discussed in more detail below, although not officially given any dispute-resolving duties, the chiefs in fact deal with all levels of disputes, from petty thieving to rape and more serious offences.

When Vanuatu achieved statehood on 30 July 1980, there was a focus on the role of customary values in the new nation. In his independence address, the first President, Father Walter Lini, noted the importance of developing "in the Melanesian way on our own" and of using "God and custom" as the "sail and steering-paddle of our canoe". This recognition of kastom also found its way into the Constitution, which provides for a pluralist system, recognising the role of both kastom and the introduced law in Vanuatu. After independence, the introduced laws were retained "until otherwise provided by [P]arliament". ${ }^{12}$

The position of kastom in the Constitution is ambiguous. On the one hand there are a number of provisions that suggest that it is envisaged that it will gradually take a more prominent role in the legal system. Article 95(2) provides that the introduced laws should be applied "wherever possible taking due account of custom". Further, article 95(2) states "customary law shall continue to have effect as part of the law of the Republic of Vanuatu". Article 52 states that Parliament is to provide for the establishment of Island Courts with jurisdiction over customary and other matters and shall provide for the role of chiefs in such Courts. On the other hand, there are hints that the legislature had a distrust of customary law, as is suggested by the requirement that the judiciary shall "resolve proceedings according to law" but "[i]f there is no rule of law applicable to a matter before it, a court shall determine the matter according to substantial justice and wherever possible in conformity with custom". ${ }^{13}$ The reference to "substantial justice" as taking precedence over kastom suggests that the drafters of the Constitution were torn between a desire to incorporate kastom, and a desire to modify those parts of it which were perhaps not seen as being in conformity with the standards of a modern nation State.

In 1983 the Parliament of Vanuatu fulfilled its constitutional obligation under article 52 and enacted the Island Courts Act 1983, which established Island Courts with jurisdiction to determine minor civil claims and criminal matters. Section 10 provided that "an island court shall administer the customary law prevailing within the territorial jurisdiction of the court so far as the same is not in conflict with any written law and is not contrary to justice, morality and good order". This

12 Constitution of Vanuatu, art 95(2).

13 Constitution of Vanuatu, art 47(1). 
reference to "justice, morality and good order" continues the tradition of legislative ambivalence about the role of kastom. Larcom noted that the passage of the Island Courts Act 1983:14

... was a crucial step in the government's attempt to construct and solidify a national cultural identity.

The Act was intended to grant decision-making authority over most local jural matters to local institutions. Apparently recognizing the inability of national legal codes to regulate social order in the villages, the government now sought to hand issues of law and justice back to village courts.

The Constitution also establishes the Paramount Council of Chiefs, known as the Malvatumauri, which has "a general competence to discuss all matters relating to custom and tradition and may make recommendations for the preservation and promotion of Ni-Vanuatu culture and languages". ${ }^{15}$ The Malvatumauri is the head of a four-level chiefly structure, which starts at the village level and moves up through area- and provincial-level councils. Thus the kastom system has been overlaid with a new hybrid power hierarchy, which consequently brings many new sets of aspirations and interests to the preservation and modernisation of kastom.

\section{LIKE SHIPS IN THE NIGHT}

Although it is clear from the above legislative framework that there is scope for the integration of the two systems, the research that has been conducted so far has found that in reality there has been very little interaction between them. ${ }^{16}$ The two systems rather pass over and through each other with little synthesis, and with surprisingly little conflict. Powles summarised the position as follows: ${ }^{17}$

On the one hand, the spheres of activity governed by customary law and the political and social investment in its retention do not appear to have diminished. The content of customary law has not been significantly altered by statutory intervention, nor has it been incorporated into a new jurisprudence. Courts and governments are unsure how to proceed. On the one hand, while a sort of 'stand off' may appear to exist, it is not a 'stalemate'. Lack of guidance for the courts as to how to handle customary law, and the increasing number of common-law trained lawyers engaged as judges and practitioners in Pacific Island legal systems, have ensured that the persistent erosion of the vitality of customary law has continued, even increased in tempo.

14 Larcom, above n 7, 176.

15 Constitution of Vanuatu, art 30(1).

16 Weisbrot, above n 2.

17 Powles, above n 2, 75. 
At the 2003 Annual Vanuatu Judicial Conference a local lawyer noted that "since the beginning of this country's claim to sovereignty the laws of the country have merely paid lip service to the effect of custom on society's administration as a mere pebble in the pond of law". ${ }^{18}$

The lack of integration of kastom into the official system is demonstrated by, amongst other things, the continued judicial reliance on Australian and British case law, the lack of any form of mediation or conciliation (the hallmark of kastom procedures), the lack of acknowledgement of kastom crimes (with the notable exception of witchcraft) or kastom defences, the insistence that kastom must be "proved" before it is accepted as a source of law, the adversarial nature of the proceedings, the use of outdated British legislation, ${ }^{19}$ and the obligation for barristers and judges to wear black woollen robes in court.

The Island Courts, in which so much hope was placed, have been largely unsuccessful in achieving the constitutional requirements that an adequate procedure for the resolution of custom disputes be established. ${ }^{20}$ This is partly due to their lack of funding, which has incapacitated the majority of them outside the main urban centres, and is partly due to their jurisdictional capacity. The specific jurisdiction of each court is defined in the warrant that establishes the particular Island Court, and the warranted jurisdiction of the Island Court, other than in the area of land, does not actually involve any general or specific custom law jurisdiction. ${ }^{21}$ Rather, the warrants indicate that the focus of the courts' jurisdiction is minor introduced law matters. ${ }^{22}$ In reality, as Weisbrot noted, the Island Courts operate as less official magistrates' courts rather than as officially sanctioned Custom Courts. ${ }^{23}$

The current operation of the kastom system has not been the subject of much research ${ }^{24}$ and consequently it is hard to determine how much it has been influenced by "white man's law".

18 Ismael Kalsakau "Judicial Approach to Pleading and Proof of Custom, Finding Custom as Fact" (Vanuatu Annual Judicial Conference, Supreme Court, Port Vila, 18 July 2003).

19 All English Acts of Parliament, generally or specifically applying to New Hebrides and in force in 1980, were continued in force by art 93 of the Constitution of Vanuatu unless they were revoked by Parliament or incompatible with the independent statutes of Vanuatu. Many have not been modified to suit the circumstances of the country.

20 See Anita Jowitt "Island Courts in Vanuatu" (1999) 3 JSPL Working Paper 3.

21 The jurisdiction over land has recently been removed from the Island Courts and a new system created, the Customary Lands Tribunals. These Tribunals in effect decentralise the resolution of issues relating to land: See Island Courts Amendment Act 2001, no 15; and Customary Land Tribunal Act 2001, no 7.

22 Jowitt, above n 20.

23 Weisbrot, above n 2, 115.

24 One exception to this is Lindstrom's work in Tanna. See Lamont Lindstrom "Straight Talk on Tanna" in Karen Ann Watson-Gegeo and Geoffrey M White Disentangling: Conflict Discourse in Pacific Societies (Stanford University Press, California, 1999) 373. 
However, it is clear from anecdotal evidence that what commonly occurs when parties go to a chief to resolve a dispute is that the chief holds a meeting to which the disputing parties, other interested parties and some village elders are invited. The parties are then given a chance to explain their actions and there is a general discussion about what has happened and the causes of the problem. At the end of the meeting the chief generally imposes a fine on one, or often both, of the parties. If a party is dissatisfied, he or she can "appeal" up the chiefly structure.

In this way kastom is the first stop for a large percentage of complainants in criminal matters. Often the matter stops there, but there are three circumstances in which it will go on to enter the official system: if the kastom fine is not paid; if one party is dissatisfied with the kastom process; or because at the height of their passion the victim has gone to the police to make a complaint and then either forgotten, or was prevented from, withdrawing it after the kastom settlement. ${ }^{25}$ The number of cases that enter the formal system is also determined by the ability of the parties to access the system. Thus, while in Vila and Luganville the number of cases before the courts is substantial, in most other areas the chiefs deal with almost every case, including, according to anecdotal evidence, murder. $^{26}$ In Vila it is also becoming increasingly common for complainants to report their cases directly to the police.

This process is illustrated by two cases. The first is Waiwo $v$ Waiwo and Banga, where the senior Magistrate (now Chief Justice) Lunabek stated: ${ }^{27}$

In addition, in Tanna like other Islands of the Archipelago, custom plays an important role in day to day life of their inhabitants. One very common example to the knowledge of the Courts and in particular Magistrates is that when the Courts hear criminal cases on Tanna, very often, the Magistrate will not be surprised to see appearing before the Court into the Accused box, next to the Accused, his custom chief. The chief pays respect to the bench and informs the Court that they have already dealt with the matter in custom and the Defendant or Accused is already punished for his wrongdoing. ... The Court explain[s] to the chief concerned the position within the criminal law, the Accused [i]s dealt with accordingly and the Court then invites the chiefs to explain the custom. Obviously the Court [does] take into account the customary settlement, compensation and punishment ... as a mitigating factor when considering the sentencing of the Accused.

25 The police sometimes enforce a "no drop" policy for certain categories of offences, for example, sexual offences.

26 A number of people from different islands have told the author that their chiefs deal with murder. The most common punishment seems to be that the life has to be replaced, and so if the murderer has a child, that child will have to be given to the family of the deceased.

27 Waiwo v Waiwo and Banga (12 February 1996) Senior Magistrates Court, Vanuatu, Civ Cas 324/1995 <http://www.paclii.org/vu/cases/VUMC/1996/1.html> (last accessed 17 June 2004). 
A similar picture is presented by the Court of Appeal decision in Public Prosecutor v Gideon. There the tone of the (expatriate) bench is less understanding: ${ }^{28}$

Customary settlement in this case was initiated by a letter from the village Chief to the respondent demanding the payment of a fine of VT30,000, a pig and mats by a specified date, failing which criminal charges would be laid against him. The demands of the letter were duly met but that did not prevent the criminal charge being laid against the respondent who might well entertain some sense of grievance. ... We were not informed whether the complainant supported the settlement demands or received anything as a result of it. We are concerned however at the suggestion in the letter that performance of customary settlement could somehow influence the laying of criminal charges in this case. We desire to dispel any notion that customary settlement can have such an effect in an offence as serious as occurred in this case where the public interest dictates that criminal charges must be laid.

Despite the Court's distress at the prospect of charges being a threat to encourage payment of a kastom fine, in reality this is often the only enforcement sanction that a chief has at his disposal and, from anecdotal evidence, it is regularly used.

\section{TOGETHER OR APART?}

A fundamental question which has not been the subject of any in-depth study is whether the people of Vanuatu in fact want kastom to become integrated into the official legal system; or whether they would view this as the State encroaching on the role of the traditional justice systems and would prefer to keep the two systems apart. It is only once this question has been answered in the affirmative that questions of why it has not happened as yet and how to achieve it are productive. One of the themes at the 2003 Annual Vanuatu Judicial Conference was "Law, Custom and Appropriate Dispute Resolution Procedures". At the conclusion of the conference the Chief Justice noted it had become clear that a fundamental question for the country was whether or not it was appropriate to merge kastom into the official legal system. His Honour observed that answering this question was a challenge for the judiciary, lawyers, members of the executive and the community. 29

The evidence which currently exists suggests that many sections of the public support an ongoing role for kastom and further empowerment of kastom. ${ }^{30}$ The fact that the unofficial systems still exist, despite the State's backing of the official system, is very clear evidence that they are supported by the general population. In 2001 the Vanuatu Juvenile Justice Project found that young

28 Public Prosecutor v Gideon (26 April 2002) Vanuatu Court of Appeal, Criminal Appeal Case No 3 of 2001 <http://www.paclii.org/vu/cases/VUCA/2002/7.html> (last accessed 17 June 2004).

29 Vincent Lunabek, Chief Justice "Law, Custom and Appropriate Dispute Resolution Procedures" (Vanuatu Annual Judicial Conference, Supreme Court, Port Vila, 18 July 2003).

30 Based on preliminary findings of the author's PhD research; and Vanuatu Cultural Centre The Report of the Juvenile Justice Project (Vanuatu Cultural Centre, Port Vila, 2003). 
people frequently prefer to have chiefs deal with them rather than the police and courts when they are in trouble. Some reasons given for this were that "they don't always understand the white man's court system and they find that the police are often brutal with them. In kastom the chiefs try to 'straighten' young people by bringing them back to the notion of respect, instead of just punishing them". ${ }^{31}$ The Juvenile Justice Report concluded by recommending that "[a] primary solution to the problems affecting juvenile justice in Vanuatu is to empower custom law". ${ }^{32}$

There are a number of indicators that suggest that chiefs are in favour of bringing kastom into the official legal system. The 1990 Constitutional Review Committee found that the chiefs saw that although they currently have a role to play in villages and Island Courts, they still face problems since the Constitution does not give them enough power to straighten out all problems. ${ }^{33}$ Further support for the integration of kastom is found in the 1995 proposal from the Malvatumauri to establish "customary courts". ${ }^{34}$ It is clear from this proposal that the chiefs envisaged that the "chiefly system of justice" should be fully integrated into the introduced, or adopted, court system rather than operating outside and parallel to it. The memorandum that accompanied the 1995 proposal notes that: ${ }^{35}$

$4 \quad$ Although the Island Courts Act was passed in 1983, the Island Courts have never achieved this unifying function [that the pre-existing systems of customary justice would become part of the judicial system of the country]. The Island Courts have always been seen as part of the court system and the chiefs have continued to exercise customary justice in the nakamal or nasara.

5 The chiefly system of justice remains important in most areas of Vanuatu, particularly those in which there is little police presence or control.

6 As it is a working system which is acknowledged by all it is wrong to treat it as some type of alternative system of justice. It should be brought fully into the judicial system.

7 At the same time it is open to abuse. Conflicts of interest may not be acknowledged, unwritten rules may be altered, and decisions may be unfair with no realistic right of appeal.

Interestingly, this last paragraph shows that the chiefs are alive to the importance of making the integration of the two systems a two-way process.

31 Jean Mitchell Young People Speak: A Report on the Vanuatu Young People's Project (Vanuatu Cultural Centre, Port Vila, 1998) 21.

32 Vanuatu Cultural Centre, above n 30, 7.

33 Lindstrom, above n 9, 224.

34 Council of Ministers' Memorandum on Customary Courts Presented by the Minister of Justice (undated).

35 Council of Ministers' Memorandum, above n 34. 
Lindstrom also stated that "both [chiefs] and state politicians argue the utility of regularising and strengthening chiefly powers to police and judge. ... Even police leaders recently suggested that chiefs establish unofficial village police forces". ${ }^{36}$ The author has had a limited opportunity to speak to village chiefs in regard to this issue, and one chief from Erromango has stated that kastom principles have started to decline as it is hard to comply with "system blong whiteman"37 as well as kastom, and has urged that law must support kastom and recognise that kastom can also bring about peace and order as well as law. He suggests that chiefs should go inside the court and assist them in dealing with cases. ${ }^{38}$

There are concerns raised by women's groups that kastom privileges men and ignores the rights of women. Jolly warned that "codifying kastom in the state - in relation to land, to law and to leadership can also reinvigorate male dominated 'traditions'. Whether this aspect of kastom is mutable only time will tell". ${ }^{39}$ However, there are also indications that women see kastom as a source of protection. For example, after Parliament failed in 2001 and 2002 to pass the Family Protection Bill, which recognised domestic violence as a crime under the laws of Vanuatu, the Department of Women's Affairs adopted a new strategy, aiming to work with the Malvatumauri to facilitate its passage through Parliament. The Department intends to convince the chiefs that the Bill is consistent with the work they already undertake in the community, and then let the Malvatumauri take the lead role in pushing for the passage of the Bill. ${ }^{40}$

Support for such integration is also found in reviews conducted in other Melanesian countries. For example, in Papua New Guinea the 1984 Clifford Report argued that there was an urgent need for policy makers to reduce the gap between official State processes - in particular, criminal justice - and the customary, or community, context in which most citizens lived. ${ }^{41}$ It also argued that there should be a major policy shift towards integration with unofficial community controls: ${ }^{42}$

36 Lindstrom, above n 9, 224

37 Meaning "the white man's system".

38 Interview with Chief Tom Kiri (the author, Erromango, March 2003).

39 Margaret Jolly Women of the Place: Kastom, Colonialism and Gender in Vanuatu (Harwood Academic Publishers, Chur, Switzerland, 1994) 258.

40 Li Fung "Developing Rights the Melanesian Way: Kastom, Human Rights and Women in Vanuatu" (2002) given to the author by Li Fung. To the best of the author's knowledge, the paper has not been published.

41 Sinclair Dinnen "Custom, Community and Criminal Justice in Papua New Guinea" in Jonathan Aleck and Jackson Rannells (eds) Custom at the Crossroads (Faculty of Law, University of Papua New Guinea, Port Moresby, 1995) 148.

42 Dinnen, above n 41, 148. 
In terms of its effect on behaviour unofficial controls are much more effective than the written law - no matter how strictly it may be enforced. Papua New Guinea has enormous advantages in this customary and community area and this report suggests their exploitation [that is] to modernise with tradition.

Dinnen argued that in Papua New Guinea the community structures are by far the strongest, but that successive governments and aid donors have tended to support the official structures at their expense. He noted that this is particularly ironic given the move towards community revivalism in parts of the developed world..$^{43}$

The majority of academic opinion on the issue of integration appears to be consistent with the following opinion by Zorn and Corrin Care: ${ }^{44}$

[W]e still find that the state legal systems of the Pacific are faced with the continuing need to infuse themselves with custom. No matter how much has changed - no matter how much its immersion into the state legal system will further change it - it is still an emanation of Pacific Island cultures in a way that the common law of England, Australia or the United States is not. If that imported common law system is to have any relevance to the island states, then it must take on a Pacific patina, in the same way that Melanesian pidgin languages, which were once purely colonial impositions, have become mixed, but still viable parts of Pacific culture.

\section{$V$ REASONS FOR THE LACK OF INTEGRATION AND LIMITATIONS OF PREVIOUS RESEARCH}

The difficulties of integrating kastom have been discussed at length by academics, largely on the basis of analysis of case law. The conclusion drawn by many academics is that bringing the two systems together would be very difficult, if not impossible - "like mixing oil and water" as one anonymous commentator put it. Fraser notes that within the University of Papua New Guinea curriculum: 45

[The] stress on the impossibility of truly integrating custom 'in practice' seems to be hardening into the same sort of shibboleth as the impossibility of truly individualised justice in the common-law educational tradition. As students elsewhere learn the need for 'certainty', regrettably, must compromise equity, students in Papua New Guinea learn that the 'inaccessibility' of custom must compromise the laudable goal of an indigenous legal system.

There are six major groupings of arguments that have been propounded for the failure of kastom to be integrated into the official system.

43 Dinnen, above $\mathrm{n} 41,150$.

44 Jean Zorn and Jennifer Corrin Care "'Barava Tru': Judicial Approaches to the Pleading and Proof of Custom in the South Pacific" (2002) 51 ICLQ 612, 638.

45 Ian Fraser "Legal Theory in Melanesia: Pluralism? Dualism? Pluralism Long Dualism?" (1999) 3 JSPL art 3. 


\section{A Constitution}

The first reason is the place in the legal hierarchy that the Constitution has given to kastom. Paterson has observed that the extent to which customary law can be applied by courts, including Island Courts, in Vanuatu, and the relationship between customary law and the common law is "shrouded in some obscurity". ${ }^{46}$ Kastom comes after the Constitution and legislation, and arguably also after the common law as a source of law. The Constitution provides in article 47(1) that the courts are to "resolve proceedings according to law" and in article 95(3) that "[c]ustomary law shall continue to have effect as part of the law of the Republic of Vanuatu". This would seem to imply that kastom and the common law are equal sources of law. However, article 47(1) goes on to provide that "[i]f there is no rule of law applicable to a matter before it, a court shall determine the matter according to substantial justice and wherever possible in conformity with custom". This leaves the door open for courts to argue that kastom only has a "fill-in" role, in other words, it is only if there is no other law available that the Court must look to custom. As Vanuatu still applies the laws of England and the laws of France as applied to, or made for the New Hebrides prior to 1980 , to the extent that they are not expressly revoked or incompatible with the independent status of Vanuatu, there are not very many areas in which an ancient British law cannot be dredged up. This is demonstrated by the case of Boe \& Taga $v$ Thomas ${ }^{47}$ where the Court was considering the question of compensation for the death of a child. Justice Cooke justified ignoring custom by finding that two old English Acts, namely the Fatal Accidents Act 1846 and the Law Reform (Miscellaneous Provisions) Act 1934 applied, and that he was therefore not compelled to turn to custom. ${ }^{48}$

The fact that kastom cannot be inconsistent with the Constitution imposes quite substantial limits on its jurisdiction, as there is a broad Bill of Rights in the Constitution which in many ways conflicts with kastom. One example of this is the regulation of movement of people between villages and islands. According to the Kastom Polisi of the Malvatumauri, "[a] man may live on another island only with the agreement of both chiefs concerned" and "[i]f a man living on another island does not listen to local chiefs and troubles the people there, the chief must give him three warnings. After the third warning, the chief may evict him to return to his home island". ${ }^{49}$ There is also anecdotal evidence that the chiefs of Erromango have a "three month policy" whereby they will allow people from the island to go to the towns to look for work for three months. If they have not

46 Don Paterson "South Pacific Customary Law and Common Law: Their Interrelationship" (1995) 21 Comm L B 668.

47 Boe \& Taga $v$ Thomas (1980-1994) Van LR 293.

48 Boe \& Taga $v$ Thomas, above n 47, 296.

49 Malvatumauri "Kastom Polisi Blong Malvatumauri" in Lamont Lindstrom and Geoffrey M White (eds) Culture, Kastom, Tradition: Developing Cultural Policy in Melanesia (Institute of Pacific Studies, University of the South Pacific, 1994) 229. 
found employment within this period then they are forced to return to the island. This eviction is often done with the assistance of compatriots in the Vanuatu police force. Lindstrom commented "many people accept [this practice's] legitimacy if not its application in particular cases". ${ }^{50}$ However, such a practice is in direct conflict with the freedom of movement guaranteed by the Constitution in article 5(1)(i).

Even in the Island Courts, kastom can only be applied if it is "not in conflict with any written law and is not contrary to justice, morality and good order". ${ }^{51}$ If the ideas of justice, morality and good order are determined by a higher court trained in the common law tradition, this also has the potential to severely limit the use of kastom.

\section{B Kastom not Homogenous Body of Law}

A second reason that has been used as an explanation why kastom has not been integrated is that kastom varies so much from community to community and island to island that it is not possible to apply it as a homogenous body of law at a national level. ${ }^{52}$

This was the view put forward by Justice Cooke in Boe \& Taga $v$ Thomas where he noted: ${ }^{53}$

Mr Rissen further submitted that I should consider the custom of the parties in assessing damages. I regret that I cannot accede to this submission of Mr Rissen as custom varies so much in each village throughout Vanuatu that it would be quite impossible to lay down guidelines for those dealing with the matter.

According to this view, if a kastom does not exist throughout Vanuatu then it cannot be recognised as a rule of law, as due to the principles of stare decisis, this would result in it becoming a precedent for the whole country.

\section{Legal Profession Trained in Common Law Tradition}

A third reason for the non-integration of kastom is that the legal profession in Vanuatu is substantially expatriate and trained in the common law tradition. A former Chief Justice, Justice d'Imecourt observed in Banga $v$ Waiwo that: ${ }^{54}$

What Parliament has not done so far, and I venture to say, is unlikely to do, is to do away with the element of British 'Common Law and Equity' that [applies] in Vanuatu. After 16 years of independence,

50 Lindstrom, above n 9, 226.

51 Island Courts Act 1983, s 10.

52 See, for example, Jennifer Corrin Care "Customary Law in Conflict: the Status of Customary Law and Introduced Law in Post-Colonial Solomon Islands" (2001) 21 UQLJ 167, 174.

53 Boe \& Taga $v$ Thomas, above n 47, 296.

54 Banga $v$ Waiwo [1996] VUSC 5. 
it would be difficult to do so. Further more, it is likely to cause enormous upheaval in the legal system if it sought to do so now. One need only to consider the fact that virtually all the country's lawyers, including the Ni-Vanuatu lawyers, are common law trained. We have also just opened a Branch of the University of the South Pacific, the Law Section for the training of law students for the Pacific. That law school teaches law applied according to the ethos of the British common law that applies not only in Vanuatu but in the whole of the South Pacific bar one exception.

This factor has had a significant impact on the inhibition of the development of a Melanesian jurisprudence. As Bourdieu noted: "The individual is always, whether he likes it or not, trapped ... within the limits of the system of categories he owes to his upbringing and training".55 Consequently, this has meant that both lawyers and the judiciary have felt more comfortable in applying the common law than custom, and have, in general, shied away from pushing the boundaries established by the Constitution.

Further, all of the judicial institutions that have been set up follow the British model and therefore allow little room for kastom processes. Narokobi argued that: ${ }^{56}$

The enforcement of English law through imposed institutions such as the courts, the executive, the

Parliament, the economy, the religious and educational systems, leaves no opportunity for the growth of any authentic theory of law, springing from Melanesian social contexts.

He also noted that "[a]ll state institutions are regulated by former colonisers' assumptions". ${ }^{57}$ In other words, there are structural barriers to the reception of kastom into the official system as well as substantive barriers. Even the Island Courts, which are ostensibly the "kastom courts", in general follow the procedures from the official system rather than kastom processes. ${ }^{58}$ The current set-up means that if kastom is to come inside the official system, it can only do so by adapting and changing to fit the forms set by the old colonial structure.

\section{Kastom Rules and their Application are not Clear}

Fourth, although Parliament is charged by article 51 of the Constitution to "provide for the manner of the ascertainment of relevant rules of custom" it has not done so. Although there was

55 Pierre Bourdieu and Loïc Wacquant An Invitation to Reflexive Sociology (University of Chicago Press, Chicago, 1992) 126.

56 Bernard Narokobi Lo Bilong Yumi Yet: Law and Custom in Melanesia (published jointly by The Institute of Pacific Studies of the University of the South Pacific, Suva and The Melanesian Institute for Pastoral and Socio-Economic Affairs, Goroka, Papua New Guinea, 1989) 6.

57 Narokobi, above n 56, 31.

58 The police prosecutor in charge of the Island Courts informed the author that the judges have no idea what procedure to follow and so he tells them what to do, based on the procedures he has learnt when prosecuting in the magistrate's court. 
initially a provision in the Criminal Procedure Code for assessors to sit in the courts to advise the judges in relation to custom, even this aid to the recognition of customary law in Vanuatu has, for unexplained reasons, been removed. Consequently, there is a level of confusion about how kastom is to be used as a source of law by the courts, which has contributed to the judiciary's reluctance to use it in preference to easily accessible introduced laws. Weisbrot stated: ${ }^{59}$

There is nothing to provide some guidance as to the integration of custom in the western-style courts on such matters as: (1) the definition of custom; (2) the subject areas in which custom is or is not applicable; (3) the modes of ascertainment and rules of evidence and procedure with respect to adducing custom in the courts; (4) the standards (if any) against which the recognition of custom must first be tested; (5) the regime to be followed in the event of a conflict of customary laws; (6) the method by which a person must establish (or refute) membership in a customary group, and so on. The experience elsewhere in the Pacific suggests that in the absence of strong guidelines and incentives to utilise custom it is very difficult for customary law to develop in a coherent and comprehensive manner.

The question of how kastom is to be proved has been considered by the courts, and although views vary, the general approach seems to be that set down by Chief Justice d'Imecourt in Banga $v$ Waiwo where he stated: ${ }^{60}$

Although it is conceivable that there might not be a need for strict rules regarding the obtaining of evidence of a particular custom if and when the need arises to establish a particular custom, evidence must, nevertheless, be obtained and a clear custom must be established.

\section{E Nature of Common Law and Kastom are Different}

Fifth there is the fact that the nature of the common law and kastom are fundamentally different. Kastom is unwritten, process driven, flexible and concerned with restoring relationships in small scale communities. As Zorn notes, the aim in kastom is: ${ }^{61}$

[T]o settle disputes, if at all possible, and, in doing so, to restore, for a time, amicable relations and to fulfil as much as possible the needs and expectations of all the parties at that time. No dispute is presumed permanently solved: the changing nature of the village land needs, populations and power relations mandate that no solution can be final, no rule impregnable. A decision that fulfilled the needs of the village at one time may not fulfil its needs at another time. To meet these aims, substantive norms must be flexible, fluid, capable of being used in different ways at different times ... .

59 David Weisbrot "Law and Native Custom in Vanuatu" (1988) 3 Law and Anthropology 103, 115.

60 Banga $v$ Waiwo, above n 54.

61 Jean Zorn "Making Law in Papua New Guinea: The Influence of Customary Law on Common Law" (1991) 14 J Pac Stud 1, 24. 
The common law, on the other hand, is fixed, universal and aims to permanently resolve a dispute. There is the concern that bringing kastom into the official system would essentially change its nature, crystallising it into an inflexible precedent; thus losing its value and purpose. Ntumy argued that when a legal norm of customary law is sanctioned by the State, either through legislation or the norm-creating activity of the courts, it is instantly converted by State power from customary form to State law. It then ceases to be customary law. He observed "[e]fforts to legislate customary law by an external political power are, therefore, the antithesis of custom". ${ }^{62}$ Zorn and Corrin Care shared this view, noting "[t]he ultimate irony of customary law is that although state law must recognise and apply custom in order to make itself a part of the culture, state law cannot use custom without turning it into something else". ${ }^{63}$

\section{F Different Views of the Players in the Dispute}

Sixth, there is the fact that the common law sees the victim and the offender as the central players in a dispute, whereas in kastom the issue is more often about one group versus another. Thus the focus in the common law is about punishment of the offender, and compensation and reconciliation is, if anything, a side issue; whereas in kastom the whole system is geared towards what is required to "right the wrong". Findlay argued that "the 'individualised rights and responsibilities' focus of both common and civil law traditions does not translate well into the communal social organisation that features in many Pacific cultures ... ". ${ }^{64}$

\section{G Conclusions}

These six explanations have been used, in various different combinations, to explain the current lack of the use of kastom in the official court system by almost every commentator on the role of kastom in Vanuatu. They are extremely useful explanations of the reasons for certain aspects of the current system, but they are limited in a number of important respects.

The first limitation is that, because the explanations are based on an analysis of case law and legislation, with very little empirical research into the real operation of each system, they do not go outside the question of the reception of kastom by the courts. However, the criminal justice system operates in many places outside the courts. It encompasses the decision about whether to report a crime, the ability to do so, and the desire and the ability of the police to investigate the crime. It also includes the decision by the police about whether or not to send the matter back to the chiefs to be dealt with; and the decision by the chiefs as to whether they will pass the complaint on to the police.

62 Michael A Ntumy "The Dream of a Melanesian Jurisprudence: the Purpose and Limits of Law Reform" in Jonathan Aleck and Jackson Rannells (eds), above n 41, 10.

63 Zorn and Corrin Care, above n 44, 635.

64 Mark Findlay "Crime, Community Penalty and Integration with Legal Officialism in the South Pacific" (1997) 21 J Pac Stud 145, 146. 
It also encompasses issues concerning punishment, including the type of punishment and whether or not the effect of one type of punishment, such as imprisonment, is the same in the Vanuatu context as it is in the western context. Finally, the criminal justice system also involves the decisions and procedures used by the chiefs in deciding the cases they deal with, and in determining the extent of their jurisdiction.

The need to go beyond the written record and to investigate the whole of the criminal justice system was forcibly brought home to me when I was working as a prosecutor in the Vanuatu Public Prosecutor's Office. On one occasion I went to do some prosecutions on the small island of Epi. One was a rape case and the offender was sentenced to three years imprisonment. I went back to Epi about six months later and talked with the police officer there. I asked him whether he had had any more rape cases. He said no, and I felt very pleased, thinking that the conviction and sentence had had a good deterrent effect. But then he said to me that everyone had thought that the punishment was too extreme and that they would not report cases any more because they did not want men to be sent away from their families, which resulted in women and children having no-one to help them to grow their food. From a documentary analysis it would appear that the deterrent of a large sentence had worked - but once the investigation went further, a completely different reality emerged.

The second limitation of the previous inquiries is that while the six reasons discussed above attempt to explain why so far there has not been any integration of kastom into the official system, they do not take the next step of investigating what changes should and can be made to each system to facilitate such integration. In other words, they are no more than explanations of the current situation, and do not go the next step of asking what changes should be made to each system to achieve further integration. In fact, there is an underlying theme in most of the explanations that both systems are fragile and brittle, and that any changes or compromises in each system would result in the collapse of the entire structure. Thus there has been no creative questioning of whether, for instance, the punitive emphasis of the official system is appropriate in a country where there are no prisoner rehabilitation programmes nor any long-standing tradition of incarceration.

Third, the six explanations focus solely on the question of integration of kastom into the official system. In other words, the process of integration is viewed as being one-way, rather than two-way. This means there has not been any consideration of how official conceptions of law are influencing, and should and can influence the unofficial legal system, as well as how customary conceptions of law are influencing, and should and can influence the official legal system.

\section{A NEW WAY FORWARD: A NEW METHODOLOGY}

The limitations of analysis based largely on case law demonstrate a need to go outside this framework, and to investigate the actual operations of the justice system "on the ground". It is proposed that the insight gained in Epi - that what is really happening cannot always be observed from documentary sources - might help to provide some solutions about whether kastom and the official system really are fundamentally incompatible, and whether they should and can be 
integrated. In other words, there is a need for empirical research to go beyond the picture that emerges from case law and to investigate whether the assumptions about the operation of kastom and the official system in Vanuatu are necessarily valid.

Support for this view comes from the only two anthropological studies that have been conducted in Vanuatu focussing on the legal systems. These two studies - one by Rodman in Ambae, ${ }^{65}$ and one by Larcom in South West Bay, Malekula ${ }^{66}$ - concerned the period leading up to, and following, independence in 1980. They reported observations of strange hybridisation of the official and unofficial legal systems that had spontaneously occurred, initiated by the local community, but supported or at least tacitly allowed by the colonial government. In many ways these observations show a much closer blending of the two systems than anything that the State has tried to create since independence.

Rodman observed that faced with the withdrawal of the colonial justice system, the inhabitants of Ambae devised for themselves a "new legal order". ${ }^{67} \mathrm{He}$ noted that the legal system proposed was complex, comprehensive, and syncretistic: it involved multiple legal layers, a system of appeals, and a codified set of laws based on a combination of traditional and non-traditional principles. ${ }^{68}$ He commented that this allowed them to avoid a pitfall that has hindered other indigenous attempts at codifying laws: disagreement over which one of several versions of custom should be incorporated into a code. ${ }^{69}$ Nothing more has been written about what has happened to this legal order in the twenty years since Rodman's last visit, although rumours suggest its continued existence.

A different approach appears to have been taken on the island of Malekula. Like Rodman, Larcom studied a community, the Mewun, both before independence and afterwards. She found that before independence "the division between local and colonial justice had settled into a stable system, with expectations and results relatively clear to both the Mewun and the BDA [British District Agent]". ${ }^{70}$ Colonial law was enforced by a native court, a meeting of colonial and local Mewun leaders held every month. The BDA essentially dealt with any cases that included assault, statutory rape and adultery. An assessor was responsible for dealing with the rest. Appeals went to the BDA, who had the power to imprison people. Larcom noted that "[e]ven when the BDA

65 William Rodman "A Law unto Themselves: Legal Innovation in Ambae, Vanuatu" (1985) 12 American Ethnologist 603

66 Larcom, above n 7, 179.

67 Rodman, above n 65, 604.

68 Rodman, above n 65, 604.

69 Rodman, above n 65, 620.

70 Larcom, above n 7, 179. 
presided, most legal cases were in effect settled according to Mewun rather than European standards of justice". ${ }^{71}$ However, after independence, "the Mewun lost the power of force that had supported social order; in exchange they gained little additional autonomy for their dispute-settling process, which they had effectively controlled for quite some time". ${ }^{72}$ Consequently they looked to the government to replace the BDA. However, the government did not leap into that role and has largely left them to their own devices. Larcom, writing just after the introduction of the Island Courts Act 1983, wrote of the anticipation of the Mewun about these Courts. As discussed above, these Courts have never really got off the ground, and it is doubtful whether the Mewun, or any other group, has found a successful replacement for the BDA.

These two case studies show that important insights can be gleaned into the possibility of fusion and hybridisation of kastom and the official legal system from empirical research. The study in Ambae, in particular, hints at possibilities of merging the two systems which could be applied to the failing Island Court system.

\section{CONCLUSION}

The debate about how to create an autochthonous legal system in Vanuatu appears to have stalled at the realisation of the immensity of the task. It is suggested that the debate can be started again by investigating the reality behind the picture presented by case law and legislation. The reported sightings of hybrid legal systems suggest that the reality may hold surprising answers as to how linkages can be made between the two systems. The empirical research plan that is proposed is to study all aspects of the operation of the unofficial and official justice systems through interviews with all major stakeholders and office bearers. It will be necessary to interview chiefs and interest groups, ${ }^{73}$ in the islands as well as the urban areas. It will also be necessary to observe the operation of kastom courts, and follow up on the studies made by Rodman and Larcom in the 1980s. These investigations will produce a more complete view of the current extent of integration of the two systems than has previously been possible. It will also allow advantages and disadvantages of further integration to be discovered, and, hopefully, provide insights into the sorts of changes that are necessary to bring about the further integration of kastom into the official legal system of Vanuatu.

71 Larcom, above n 7, 180.

72 Larcom, above n 7, 180.

73 For example, women's groups. 